\title{
Policies and Practices of the Doctoral Programs in English Language Teaching in Turkey
}

\author{
Kemal Sinan Ozmen ${ }^{1} \&$ Betul Kinik ${ }^{1}$ \\ ${ }^{1}$ Gazi University, Turkey \\ Correspondence: Betul Kinik, Gazi University, Turkey. E-mail: kinikbetul@ gmail.com
}

Received: September 16, 2015

Accepted: October 2, 2015

Online Published: October 6, 2015

doi:10.5430/ijhe.v4n4p188

URL: http://dx.doi.org/10.5430/ijhe.v4n4p188

\begin{abstract}
The present review focuses on the doctoral programs and dissertations in the field of English language teaching between the period 2010 and 2015 in Turkey to reveal how the latest reforms on higher education shaped the programs, supervisors, students and dissertations. This research focus requires immediate attention as there is not yet an established body of literature addressing how the National Qualifications Framework of Higher Education, as the national interpretation of the European higher education policies, works in practice across doctoral programs. To this end, 13 graduate programs on English language teaching were analyzed in 2014-2015 academic year in terms of program structure, courses, supervisors and students. In addition, 137 doctoral dissertations written in those programs between 2010 and 2014 were investigated with regards to their subject areas and research focus and how those two factors were distributed across the programs. Findings indicate that although the national qualifications framework seems to contribute to the programs significantly in terms of standardization, nation-wide policies are necessary to expand the impact of doctoral dispositions beyond academia, and that further research studies are needed to yield data about the scholarly impact of those doctoral programs.
\end{abstract}

Keywords: European Union higher education policies, Turkish higher education policy, Doctoral programs, Doctoral dissertations, English language teaching

\section{Introduction}

Doctoral degree studies in English language teaching (ELT) in Turkey dates back to the establishment of the Council of Higher Education (CHE) in 1981. Although those doctoral programs have been serving for the academia for more than three decades, no studies have so far reported on their current practices and policies in terms of both national and international standards. To this end, this review investigates the doctoral programs in ELT in Turkey by referring to 13 national accredited programs and their current studies in the academic year 2014-2015 as well as 137 dissertations completed in those programs between the period 2010 and 2014. The review specifically focuses on the details of program structure and organization, course types, major characteristics of the completed dissertations, and how all those are shaped in line with the current national and international policies.

Over the last decade, the educational policies of the European Union have been quite influential in shaping national policies at every level, including doctoral programs in ELT. The Council of Higher Education (CHE, 2015) has already completed a nation-wide project called "National Qualifications Framework for Higher Education in Turkey", in which the standards and the outcomes of doctoral degree programs are designated in detail. In this regard, the present review addresses both global and local developments on doctoral level education in ELT to unravel the current academic and political zeitgeist that characterizes the doctoral studies nationally.

On a global scale, although doctoral education and doctorateness as a theoretical construct are under scrutiny with regards to certain socio-economic and academic variables (eg. Christensen, 2005; Halse \& Mowbray, 2011; Wellington, 2013), there seems to be a consensus on the major characteristics of a doctoral graduate. That is to be an autonomous and a resourceful researcher who has the necessary competences to serve the academia and community (Wellington, 2013). Perhaps intuitively, doctoral graduates, or competent researchers, are viewed as the natural part of academia and future professors of their field. However, the only employers of PhDs are not, and should not be, the higher education institutions. The fact is that $50 \%$ of EU and $70 \%$ of USA PhD graduates are employed outside universities for both research and non-research posts (Borrell-Damien, 2009; Council of Graduate Schools, 2008). Similarly, Thomson and Walker (2010) notes that only around 35\% of doctoral graduates are employed for research 
posts in the UK. However, in the present study, it is inferred that around $98 \%$ of the national ELT doctoral graduates in Turkey work at state or foundation universities as research assistants or lecturers, and the rest $2 \%$ probably work as teachers in various state or private primary and/or secondary schools. Therefore, the motivation of almost all of the ongoing PhDs of ELT programs is to find an in-campus academic post.

As Turkey is a part of the Bologna Process and European Higher Education Arena, it is important to recall how the EU approach to doctoral programs has been articulated recently. During the EU Bologna seminar, Christensen (2005) states that the major role of doctoral degrees is to expand knowledge via original research, and that doctoral graduate should not be employed only by academia (see also Commission of the European Communities, 2003). Evidently, macro level policies in Turkey do not enable ELT doctorates to get employed outside the university contexts. In a sense, this is not a task of graduate programs or universities. Then, who is responsible for the motivation and objective of incoming students to doctoral programs in ELT? Council of Higher Education, the centralized institution managing universities, embarked on an important project in 2006, entitled "National Qualifications Framework for Higher Education in Turkey" (NQF-HETR). It is reported that the first attempts of designing a national qualifications framework is based on the Ministers' Conferences in Bergen in 2005, as a part of Bologna process (CHE, 2015). Therefore, this national project has already completed the design, planning and piloting phases. In 2015, the higher education institutions are expected to comply with the quality assurance standards of the NQF-HETR to certify that the national competences are in line with the European qualification standards. For the NQF-HETR, doctoral programs (as the $8^{\text {th }}$ level in educational cycles) last around 3-4 years with ECTS (Note 1) 60 credits maximum per annum or between ECTS 180 and 240 credits in total. The national framework describes doctoral level education under three major areas: knowledge (theoretical), skills (cognitive and procedural) and capabilities including four major sub-dimensions. Those sub-dimensions are 1) capability of working independently and taking responsibility, 2) capability of continuous learning, 3) capability of social interaction and 4) field specific capabilities. The NQF-HETR defines each major and sub-categories in terms of what a doctoral graduate know, do and be competent about (NQF-HETR, 2015), such as 'can understand the interdisciplinary interaction of the field' for the knowledge area or 'evaluate and use new information within the field in a systematic approach'.

To define its philosophical and political grounds, the NQF-HETR refers to the major qualifications of the EU and defines all ISCED (Note 2) levels of higher education accordingly. One of those EU-based qualification frameworks is the "National Qualifications Framework" (NQF-HETR, 2015), which is based on definitions and approaches closest to the economic status, social and cultural background of the given country, while offering comprehensible and comparable educational degrees, recognized both nationally and internationally (NQF-HETR, 2015). Another reference framework of the NQF-HETR is the "Overarching Framework for Qualifications of European Higher Education Area", which describes each cycle of higher education with comparable and transparent descriptors with regards to workload, level, learning outcomes, competences and profile (EHEA, 2015). One other critical framework addressed in the NQF-HETR is the "European Qualifications Framework for Lifelong Learning", epitomizing each level of education, including higher education, by referring to the lifelong learning principles by using descriptors in terms of knowledge, skills and competences. Those philosophical and political infrastructures of the EU have shaped the educational policies of Turkey, and thus have characterized the national higher education policies within the "European Higher Education Arena" since the country participated in the Bologna process.

Within this context, the present review elaborates on the current practice of doctoral degree programs in ELT in terms of the 1) structure and organization, 2) profile of students, 3) profile of professors, and 4) major characteristics of the doctoral dissertations. To this end, all of the ELT doctoral programs $(\mathrm{N}=13)$ were investigated in the academic year 2014-2015. In addition, 137 doctoral dissertations completed between the period 2010 and 2014 were analyzed to reach an in-depth descriptive review. Another objective of this review is to make grounded suggestions of policy and practice for the doctoral programs. Four major areas of the research focus with their specific sub-variables are presented in Table 1. 
Table 1. Areas of research focus in the current practice of doctoral degree programs in ELT

\begin{tabular}{ll}
\hline \multicolumn{1}{c}{ Area of Focus } & \multicolumn{1}{c}{ Variables analyzed } \\
\hline Structure and organization of & - General characteristics: Structure and organization \\
the doctoral ELT programs & - Compulsory and elective courses \\
& - Course distribution across universities \\
& - Grant/Scholarship opportunities \\
- Ntudents & - Nationality of the students \\
& - Pronder distribution \\
Professors & - Rank distribution of the professors \\
& - Rank distribution of professors across programs \\
& - Certain educational background and nationalities \\
Dissertations & - Sistribution of dissertations across programs \\
& - Adopted research paradigms across programs \\
\hline
\end{tabular}

\section{Method}

The analysis procedure is two-folds. First, the data concerning the program components, such as graduation requirements, courses, credits, students and professors were driven from the academic year 2014-2015. All of the Turkish universities offering an ELT PhD program $(\mathrm{N}=13)$ were included in the analysis to secure the quality of generalizations and conclusions reached in the review. The data about the doctoral programs were mostly taken from the official internet sites of the universities. The documents giving the details of compulsory and elective courses, the numbers of the faculty, the rules and regulations of the programs and all other relevant information were obtained from the internet pages of the programs. In addition, the details about comprehensive examinations or dissertation committees were reached through analysis of the regulations of the institutions. The analyses of doctoral dissertations also revealed data about the programs, such as number of graduates per year, commonly investigated subject areas and common research paradigms adopted in the programs. Those data were then thematically categorized throughout cyclical data reading sessions and cross-checking of the authors. Where necessary, specific data were quantified, such as rank of supervising professors, profile of students and courses.

Second analysis procedure concerns the dissertations completed within those programs between the period 2010 and 2014. The records of the National Theses Database show that the total number of dissertations on English language teaching between 2010 and 2014 is 137 . The analysis of dissertations were limited to their relevance to the program profiles, and only three macro factors (see Table 1) about the dissertations were discussed within this review. Firstly, a distribution of dissertations across universities was calculated by referring to the records of the National Theses Database. Secondly, the subject areas of the dissertations were first identified throughout a data-driven process in which the authors cyclically read the abstracts, key words, and specific parts of the dissertations. To secure the comprehensiveness of the thematic subject areas, fundamental disciplines of ELT, such as second language acquisition and discourse analysis were utilized as major superordinate themes. Then the dissertations were classified under those broad subject areas by referring to the key words, conceptual frames and specifically research foci of the dissertations. As a second step, the subject area categorization was distributed across 13 programs to find out the research concerns of each ELT doctoral program. Thirdly and finally, the research paradigms adopted in the dissertations were yielded via same analysis and reporting procedures utilized in the second phase.

\section{Findings and Results}

This section includes three major subsections: 1) Structure and organization of the programs, 2) Studies, supervisors and students, and 3) Characteristics of the dissertations across programs. Recommendations on policy and practice are based on the findings and interpretation of the first three subsections as well as the insights of certain national and international studies and presented in the last section.

\subsection{Structure and organization of the programs}

All of the programs offer ELT courses in English. In addition, 12 programs supervise dissertations in English language. However, Ankara University publishes dissertations in Turkish, and Istanbul University publishes dissertations in both Turkish and English. In the period 2010-2014, 25 (17.9\%) of the ELT dissertations written in Turkish, and 114 in English (82.1\%). Table 2 below shows the distribution of dissertations across universities between 2010 and 2014. 
Table 2. The number of the dissertations between 2010/2014 across universities

\begin{tabular}{|c|c|c|c|c|c|c|}
\hline Universities & 2010 & 2011 & 2012 & 2013 & 2014 & $\begin{array}{r}\text { Total } \\
\text { for } \\
\text { programs }\end{array}$ \\
\hline $\begin{array}{l}\text { Abant İzzet Baysal } \\
\text { University* }\end{array}$ & - & 1 & - & - & 1 & 2 \\
\hline Anadolu University & 5 & - & 2 & - & 3 & 10 \\
\hline Ankara University & 1 & 7 & 1 & - & - & 9 \\
\hline Atatürk University & 1 & 1 & 2 & 1 & 4 & 9 \\
\hline Boğaziçi University & 1 & - & 2 & - & 1 & 3 \\
\hline $\begin{array}{l}\text { Çanakkale } 18 \text { Mart } \\
\text { University }\end{array}$ & - & - & - & 1 & 2 & 3 \\
\hline Çukurova University & 2 & 5 & 4 & 2 & 1 & 14 \\
\hline Dokuz Eylül University & 4 & 2 & - & - & - & 6 \\
\hline Firat University* & - & 1 & - & 1 & - & 2 \\
\hline Gazi University & 10 & 1 & 9 & - & 8 & 28 \\
\hline Hacettepe University & 3 & 2 & 3 & - & - & 8 \\
\hline İnönü University* & - & 1 & - & - & 1 & 2 \\
\hline İstanbul University & 5 & 4 & 2 & 4 & - & 15 \\
\hline Mersin University & 1 & - & 1 & - & 2 & 4 \\
\hline $\begin{array}{l}\text { Middle East Technical } \\
\text { University (METU) }\end{array}$ & 1 & 4 & 9 & 2 & 2 & 18 \\
\hline $\begin{array}{l}\text { Necmettin Erbakan } \\
\text { University* }\end{array}$ & - & - & 1 & 1 & - & 2 \\
\hline Yeditepe University & - & - & 2 & 1 & - & 3 \\
\hline Yıldız Teknik University & - & - & - & - & 1 & 1 \\
\hline Total for years & 34 & 29 & 38 & 13 & 26 & 140 \\
\hline
\end{tabular}

* Those universities do not have an accredited doctoral program on ELT.

Grant and funding opportunities provided for the students were found to be quite limited. Based on the data provided in the dissertations, it was found that only 12 dissertations in 5 programs were supported by an internal or external grant mechanism. University’s own grant office supported 9 dissertations at Anadolu $(\mathrm{N}=1)$, Boğaziçi $(\mathrm{N}=1)$, Çukurova $(\mathrm{N}=1)$, METU $(\mathrm{N}=1)$ and İstanbul $(\mathrm{N}=5)$ universities. Other 3 dissertations were supported by The Scientific and Technological Research Council of Turkey.

It is observed that all of the doctoral ELT programs define their educational organization in line with the NQF-HETR and thus structurally comply with the EU higher education policies. However, there are drastic variations in terms of course load across semesters. It is therefore difficult to make consistent generalizations on how courses are offered and run in those PhD programs. Although all of the programs offer 30 ECTS credits per semester, number of courses vary slightly from 8 to 10 totally. Most of the programs distribute those courses to three semesters, such as Çağ University and Çanakkale 18 Mart University, or they seem to leave it to the pace of the students. A regulation published Council of Higher Education in 2012 states that students cannot be expelled from a higher education program due to their educational activities. Therefore, even if the students do not complete their courses in two years, they are not dismissed from the program.

ELT courses on Table 3 refer to any subject area of linguistics and applied linguistics that have a relevance with foreign language teaching. To give some examples, Anadolu University offers ELT courses entitled 'Current issues in language teaching' and 'Linguistics and language teaching'. Hacettepe University has similar courses in the program, such as 'Foreign language teaching and applied linguistics' and 'Contemporary trends in foreign language teaching'. All of the programs also offer Linguistics courses, which are not the dominating courses across the 
programs. The linguistics courses vary from 'Discourse Analysis' (Çă̆, METU, Yeditepe), 'Psycholinguistics' (Anadolu, Çăg, Gazi, METU and Yeditepe) to several aspects of bilingualism (Anadolu, Boğaziçi and Yeditepe). It is evident that linguistics courses are not too specific or irrelevant for an ELT doctoral program and do not include independent courses on micro-linguistics, such as morphology or syntax. Some programs also include elective literature courses in ELT doctoral programs. Dokuz Eylül University offers 8 courses related to either literature or teaching literature. Atatürk University has 5 literature related courses, Gazi 3, Mersin 2 and Hacettepe 1.

Table 3. Distribution of compulsory and elective courses in the ELT PhD programs across universities

\section{Course Areas}

\begin{tabular}{|c|c|c|c|c|c|c|c|c|c|c|c|c|c|c|c|c|c|c|c|c|}
\hline \multirow[b]{2}{*}{ Universities } & \multicolumn{2}{|c|}{ 目 } & \multicolumn{2}{|c|}{ 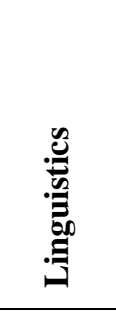 } & \multicolumn{2}{|c|}{ 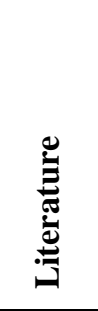 } & \multicolumn{2}{|c|}{ 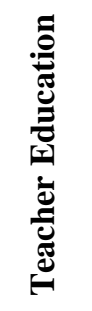 } & \multicolumn{2}{|c|}{ 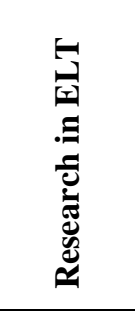 } & \multicolumn{2}{|c|}{ 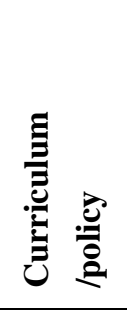 } & \multicolumn{2}{|c|}{ 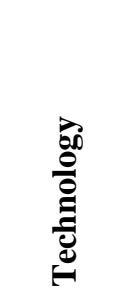 } & \multicolumn{2}{|c|}{$\stackrel{*}{0}$} & \multicolumn{2}{|c|}{ 蓠 } & \multicolumn{2}{|c|}{ 产 } \\
\hline & $\mathrm{C}$ & $\mathrm{E}$ & $\mathrm{C}$ & $\mathrm{E}$ & $\mathrm{C}$ & E & $\mathrm{C}$ & $\mathrm{E}$ & $\mathrm{C}$ & $\mathrm{E}$ & $\mathrm{C}$ & $\mathrm{E}$ & $\mathrm{C}$ & $\mathrm{E}$ & $\mathrm{C}$ & $\mathrm{E}$ & $\mathrm{C}$ & $\mathrm{E}$ & $\mathrm{C}$ & $\mathrm{E}$ \\
\hline Anadolu & 3 & 2 & 1 & 2 & - & - & - & 1 & 1 & 1 & - & - & - & - & - & - & - & - & 5 & 6 \\
\hline Ankara & - & 11 & - & 3 & - & - & - & - & - & 1 & - & 1 & - & - & - & - & - & - & - & 16 \\
\hline Atatürk & - & 10 & - & - & - & 5 & - & - & - & - & - & - & - & - & - & - & - & 2 & - & 17 \\
\hline Boğaziçi & - & 2 & 1 & 2 & - & - & - & 1 & 1 & 1 & - & 1 & - & - & - & - & - & 2 & 2 & 9 \\
\hline Çăg & 1 & 4 & - & 4 & - & - & - & 3 & 1 & 1 & - & 2 & - & - & - & - & 1 & 2 & 3 & 16 \\
\hline ÇOMÜ & - & 5 & - & 1 & - & - & - & - & 3 & 1 & - & 3 & - & 1 & - & 1 & 1 & 1 & 4 & 13 \\
\hline Çukurova $* * *$ & & & & & & & & & & & & & & & & & & & & \\
\hline DEU & - & 4 & - & 3 & - & 8 & - & 1 & - & 1 & - & - & - & - & - & - & - & - & - & 17 \\
\hline Gazi & - & 6 & - & 1 & - & - & - & 1 & - & 1 & - & 2 & - & 1 & - & 1 & - & - & - & 13 \\
\hline Hacettepe & 2 & 6 & - & - & - & - & - & 1 & - & 2 & - & 1 & - & - & - & 1 & - & - & 2 & 11 \\
\hline Mersin & 3 & 4 & - & 1 & - & - & 2 & 1 & - & 2 & - & 3 & - & - & - & - & - & 1 & 5 & 12 \\
\hline METU & 2 & 2 & - & 3 & - & - & 1 & - & 2 & 1 & - & 2 & - & 1 & - & - & - & - & 5 & 9 \\
\hline Yeditepe & 3 & 3 & 1 & 3 & - & - & 2 & - & 2 & 3 & 1 & 2 & - & 1 & - & 1 & 1 & - & 10 & 13 \\
\hline
\end{tabular}


Another two important issues covered within ELT programs are courses on research skills and teacher education. Almost all of the programs devote credits on both of the courses. While teacher education is covered in one or two courses in most of the programs, research courses seem to be more abundant. While Atatürk University has no ELT related research course, Ankara, Dokuz Eylül and Gazi have 1 ELT specific research course, and the numbers of the rest vary between 2 and 3 courses.

The next phase offered in the programs is the comprehensive examination, which is generally defined in the third or fourth semester of the programs with 30 ECTS credits, despite minor exceptions in few programs. One problem was found with how comprehensive exams are conducted; limited information is available on websites of most programs. Including the credits defined for the courses and comprehensive examination, the total number of ECTS credits offered before dissertation writing is 120 , which means half of the credits in the programs are devoted to dissertation writing. Dissertation credits, 120 ECTS in two years, are generally separated into four semesters in 30 credits as courses entitled 'field work', or as 'specialty course'.

\subsection{Supervisors and students}

Between 2010 and 2014, 80 supervisors served for the writing of 137 dissertations in Turkey (Table 4). Based on the information provided in the official web pages of those faculty members, 69 of them $(86.25 \%)$ had either a MA or a $\mathrm{PhD}$ education or worked as a fellow or a visiting lecturer/researcher in a foreign country, mostly the USA, the UK and the EU area. Almost all of those faculty are Turkish, and very few international professors serve in the programs. As one may find it interesting, the number of assistant professors supervising doctoral dissertations exceeds that of associate professors.

Table 4. Distribution of doctoral dissertations and rank of the supervisors (2010-2014)

\begin{tabular}{lcc}
\hline \multicolumn{1}{c}{ Rank of the Supervisors } & Number of Supervisors & Number of Dissertations \\
\hline Professor doctor & 39 & 86 \\
Associate professor doctor & 16 & 21 \\
Assistant professor doctor & 25 & 32 \\
TOTAL & 80 & $139 *$ \\
\hline
\end{tabular}

*Two dissertations were supervised by both professors and assistant professor doctors; therefore, the total number is 139.

Table 5 below illustrates the distribution of faculty members across programs and the number of dissertations completed in those programs in the period 2010-2014. Gazi University evidently produces more dissertations than any other programs $(\mathrm{N}=28)$. Then comes METU, İstanbul, Hacettepe and Çukurova Universities. On the grounds that there are not yet available data concerning the scholarly impact of doctoral research in this specific area in Turkey, we cannot infer the quality of the studies merely with the data presented in Table 5. 
Table 5. Faculty members across ELT programs in Turkey and number of dissertations (2010/14)

\begin{tabular}{lccccc}
\hline \multicolumn{1}{c}{ Universities } & Prof & Assoc. Prof & Assist. Prof & Total & N of Dissertations \\
\hline Abant İzzet Baysal & 1 & 1 & - & - & 2 \\
Anadolu & 5 & 2 & 7 & 14 & 10 \\
Ankara & 3 & 4 & 1 & 8 & 9 \\
Atatürk & 1 & - & 5 & 6 & 9 \\
Boğaziçi & 3 & 3 & 3 & 9 & 3 \\
Çağ & - & 1 & 3 & 4 & - \\
Çanakkale 18 Mart & 1 & 3 & 4 & 8 & 3 \\
Çukurova & 4 & 5 & 7 & 16 & 14 \\
Dokuz Eylül & 1 & 1 & 6 & 8 & 6 \\
Fırat & 2 & 1 & 3 & 6 & 2 \\
Gazi & 1 & 8 & 7 & 16 & 28 \\
Hacettepe & 2 & 3 & 5 & 10 & 8 \\
İnönü & - & 2 & 3 & 5 & 2 \\
İstanbul & - & - & 8 & 8 & 15 \\
Mersin* & 3 & - & - & - & 4 \\
METU & 2 & 7 & 9 & 18 & 2 \\
Necmettin Erbakan & 1 & 3 & 4 & 8 & 3 \\
Yeditepe & 1 & - & 4 & 5 & 1 \\
Y1ldız Technical & 1 & 5 & 5 & 11 &
\end{tabular}

*Mersin university ELT program invites 3 professors from the linguistics program of the university.

Among 71 female and 68 male students studied in those programs between 2010 and 2014, 128 were Turkish and the rest 12 were international students. The gender distribution was quite balanced and promising compared to some countries (Nerad \& Heggelund, 2008). Generally, international students came from the Middle Eastern countries (N= 10). One student was from the USA and 2 are Russian. The distribution of international students to the programs is that 3 of them studied at Atatürk University, 3 at Gazi, 2 at Hacettepe, 3 at METU and 1 student graduated from Yeditepe University. We were able to find out the current occupations of 118 national PhDs and revealed that 114 of them currently work at a university in different positions as research assistants, lecturers, assistant or associate professors. As a matter of fact, this is surely far away from the non-campus employment rates of the developed countries (Borrell-Damien, 2009; Council of Graduate Schools, 2008) and the EU policies on higher education (Christensen, 2005). This is also the point where we need to question the influence of NQF-HETR (CHE, 2015), which is to be supported by wider national policies to stretch the impact area of the Europeanization efforts.

\subsection{Characteristics of the dissertations across programs}

The dissertations produced in those programs are found to be in line with the contemporary studies in international arena (see Stapleton, 2013). We initially classified the dissertations under major disciplines of the ELT and then another classification was done under those major themes so as to secure the comprehensiveness of the major and sub-themes. Table 6 below shows the major classification of the dissertations, and Table 7 illustrates the distribution of the major themes across the programs. Thus, concerns and expertise of the each program can be inferred from the Table 7.

Table 6. Subject areas of the doctoral dissertations on ELT in Turkey between 2010 and 2014

\begin{tabular}{lll}
\hline Major Subject Areas & $\mathbf{N}$ & $\mathbf{\%}$ \\
\hline Teaching English as a foreign language & 76 & $52 \%$ \\
Foreign language teacher education & 44 & $31 \%$ \\
Discourse analysis & 14 & $10 \%$ \\
Second language acquisition & 10 & $7 \%$ \\
TOTAL & $\mathbf{1 4 4}$ & $\mathbf{1 0 0 \%}$ \\
\hline
\end{tabular}

*The actual number of dissertations is 137 . However, 7 dissertations, mostly interdisciplinary, cannot be limited to one major subject area and thus the frequency is presented as 144 . 
Expectedly, 'Teaching English as a foreign language' is the major subject (52\%) characterizes 76 local dissertations. This category includes issues on teaching language skills and components, as well as contemporary issues on learners and learning, such as learner autonomy, learning strategies and technology in foreign language learning. Although category of teacher education seems to be the second dominant category, our further analysis revealed that 20 of the 44 dissertations are about 'language proficiency of the student teachers (32\%). This is surprising, as Alptekin and Tatar (2011) pointed out "..., a teacher education programme is essentially assessed in terms of the English proficiency of its graduates, for which (ironically) it is not responsible" (p. 339).

Table 7. Subject areas of the dissertations published in Turkey between 2010 and 2014 across universities

\begin{tabular}{|c|c|c|c|c|c|c|c|c|c|c|}
\hline \multirow[t]{2}{*}{ Universities } & \multicolumn{2}{|c|}{$\begin{array}{c}\text { Foreign } \\
\text { Language } \\
\text { Teacher Edu. }\end{array}$} & \multicolumn{2}{|c|}{$\begin{array}{c}\text { Teaching } \\
\text { English as a } \\
\text { Foreign Lan. }\end{array}$} & \multicolumn{2}{|c|}{$\begin{array}{c}\text { Second } \\
\text { Language } \\
\text { Acquisition }\end{array}$} & \multicolumn{2}{|c|}{$\begin{array}{c}\text { Discourse } \\
\text { Analysis }\end{array}$} & \multicolumn{2}{|r|}{ TOTAL } \\
\hline & $\mathbf{f}$ & $\%$ & $\mathbf{f}$ & $\%$ & $\mathbf{F}$ & $\%$ & $\mathbf{f}$ & $\%$ & $\mathbf{f}$ & $\%$ \\
\hline Abant I. & - & - & 2 & 3 & - & - & - & - & 2 & 1 \\
\hline \multicolumn{11}{|l|}{ Baysal* } \\
\hline Anadolu & 6 & 13 & 1 & 1 & 1 & 10 & 2 & 14 & 10 & 7 \\
\hline Ankara & 1 & 2 & 6 & 8 & 1 & 10 & 1 & 7 & 9 & 6 \\
\hline Atatürk & 2 & 4 & 7 & 9 & - & - & - & - & 9 & 6 \\
\hline Boğaziçi & - & - & 3 & 4 & 1 & 10 & - & - & 4 & 3 \\
\hline Çanakkale & 2 & 4 & 1 & 1 & - & - & - & - & 3 & 2 \\
\hline Çukurova & 3 & 7 & 8 & 11 & 2 & 20 & 3 & 21 & 16 & 11 \\
\hline Dokuz Eylül & - & - & 5 & 7 & - & - & - & - & 5 & 3 \\
\hline Firat * & - & - & 2 & 3 & - & - & - & - & 2 & 1 \\
\hline Gazi & 16 & 36 & 10 & 13 & - & - & 3 & 21 & 29 & 20 \\
\hline Hacettepe & 3 & 7 & 4 & 5 & - & - & - & - & 7 & 5 \\
\hline İnönü * & - & - & 2 & 3 & - & - & - & - & 2 & 1 \\
\hline İstanbul & 3 & 7 & 7 & 9 & 1 & 10 & 3 & 21 & 14 & 10 \\
\hline Mersin & 2 & 4 & 1 & 1 & 1 & 10 & - & - & 4 & 3 \\
\hline METU & 5 & 11 & 12 & 16 & 3 & 30 & 2 & 14 & 22 & 15 \\
\hline Necmettin E.* & - & - & 2 & 3 & - & - & - & - & 2 & 1 \\
\hline Yeditepe & 2 & 4 & 1 & 1 & - & - & - & - & 3 & 2 \\
\hline Y1ldız Teknik* & - & - & 1 & 1 & - & - & - & - & 1 & 1 \\
\hline \multirow[t]{2}{*}{ TOTAL } & 45 & 100 & 75 & 100 & 10 & 100 & 1 & 100 & $144 * *$ & 100 \\
\hline & & & & & & & 4 & & & \\
\hline
\end{tabular}

*Those universities do not have an accredited PhD program on ELT.

** Actual number of the dissertations is 137. Some dissertations were categorized under more than one themes.

As Table 7 suggests, Anadolu, Çukurova, İstanbul and METU show a fair distribution across the subjects covered in the dissertations. Atatürk University focuses on foreign language teacher education (FLTE) and teaching English as a foreign language (TEFL); Boğaziçi primarily focuses on TEFL and second language acquisition (SLA); Çanakkale 18 Mart on FLTE and TEFL; Dokuz Eylül mostly on TEFL, Gazi on FLTE and TEFL; Hacettepe on FLTE and TEFL; and Yeditepe seems to focus on FTLE and TEFL.

Research methodologies of the 137 dissertations clearly show the dominance of quantitative and mixed method designs (see Table 8). Only 7 dissertations are found to be purely qualitative across 6 different programs. The rest 32 are purely quantitative or based on a mixed method design $(\mathrm{N}=97,71 \%)$. Our further analysis of the methodology sections of the dissertations revealed that the mixed method designs are also based heavily on the quantitative 
techniques; that is to say, most of the research questions or hypotheses are addressed via quantitative methodologies. Qualitative data are almost unanimously utilized to support the quantitative findings or for triangulation.

Table 8. Research designs of the ELT dissertations across universities

\begin{tabular}{|c|c|c|c|c|c|c|c|c|}
\hline \multirow{3}{*}{ Universities } & \multicolumn{8}{|c|}{ Research Designs } \\
\hline & \multicolumn{2}{|c|}{ Qualitative } & \multicolumn{2}{|c|}{ Quantitative } & \multicolumn{2}{|c|}{ Mixed } & \multicolumn{2}{|c|}{ TOTAL } \\
\hline & $\mathbf{F}$ & $\%$ & $\mathbf{f}$ & $\%$ & f & $\%$ & f & $\%$ \\
\hline Abant İzzet Baysal* & - & - & 1 & 3 & 1 & 1 & 2 & 1 \\
\hline Anadolu & - & - & - & - & 10 & 10 & 10 & 7 \\
\hline Ankara & - & - & 5 & 16 & 4 & 4 & 9 & 7 \\
\hline Atatürk & - & - & 1 & 3 & 8 & 8 & 9 & 7 \\
\hline Boğaziçi & 1 & 14 & - & - & 1 & 1 & 2 & 1 \\
\hline Çanakkale 18 Mart & - & - & - & - & 3 & 3 & 3 & 2 \\
\hline Çukurova & 1 & 14 & 1 & 3 & 12 & 12 & 14 & 10 \\
\hline Dokuz Eylül & - & - & 4 & 13 & 1 & 1 & 5 & 4 \\
\hline Firat* & - & - & 1 & 3 & 1 & 1 & 2 & 1 \\
\hline Gazi & - & - & 5 & 16 & 23 & 24 & 28 & 21 \\
\hline Hacettepe & - & - & 5 & 16 & 2 & 2 & 7 & 5 \\
\hline İnönü* & - & - & - & - & 2 & 2 & 2 & 1 \\
\hline İstanbul & 2 & 29 & 7 & 22 & 6 & 6 & 15 & 11 \\
\hline Mersin & 1 & 14 & - & - & 3 & 3 & 4 & 3 \\
\hline METU & 1 & 14 & 1 & 3 & 16 & 16 & 18 & 13 \\
\hline Necmettin Erbakan* & - & - & - & - & 2 & 2 & 2 & 1 \\
\hline Yeditepe & 1 & 14 & - & - & 2 & 2 & 3 & 2 \\
\hline Y1ldız Teknik* & - & - & 1 & 3 & - & - & 1 & 1 \\
\hline TOTAL & 7 & 100 & 32 & 100 & 97 & 100 & $136^{*}$ & 100 \\
\hline
\end{tabular}

* Those universities do not have an accredited program on PhD in ELT

** One dissertation was excluded from this analysis as it did not have a research design.

\section{Conclusion and Recommendations}

The present review focuses on doctoral programs and dissertations in English language teaching in Turkey. While the programs were analyzed in their current status in 2014/2015 academic year, 137 doctoral dissertations written in the last five years were reviewed. Referring to the EU policies and concrete frameworks that shape the National Qualifications Framework for Higher Education in Turkey (CHE, 2015), the present study revealed the following points on doctoral education in ELT:

1. All of the programs comply with the EU standards on higher education and refer to the NQF-HETR as the national interpretation of the philosophy behind European Higher Education Arena (see e.g. EHEA, 2015).

2. Although programs vary significantly in terms of course types, credit distributions, comprehensive exams and research foci in doctoral dissertations, they offer a clear syllabus showing overall pace toward the degree completion. However, more information is needed specifically for the international students.

3. Dissertations were found to be timely compared to international equivalents (see Stapleton, 2013), but we do not know about the quality and impact of those doctoral research.

4. While gender distribution of the doctoral students is fairly balanced, internationalization is found to be a problem.

5. Almost all of the doctoral graduates between 2010 and 2014 work at academic positions at universities, which does not comply with the contemporary understanding and role of doctorateness in the community and with the EU policies (see Christensen 2005). 
One of the major driving forces for countries awaiting the EU membership is the role of high-quality doctoral education, providing the vital corpus of skilled people for advanced economies and knowledge societies (Ginerva House, 2010; Kehm, 2004; Research Councils UK, 2009). In practice, an English school teacher who aspire to contribute to the whole educational system should clearly know that pursuing a doctoral degree will definitely result in higher posts in the Ministry of National Education or in similar bodies. Advanced research and its thinking dispositions are to stretch its boundaries and to be valued beyond the campuses. This is largely dependent upon the national legislations and efforts to welcome $\mathrm{PhD}$ graduates in governmental and private institutions.

The latest higher education reforms across universities have been a true challenge for both universities and Council of Higher Education over the last decade in Turkey. Nevertheless, the NQF-HETR, as the national interpretation of the Bologna process and the frameworks concerned, was found to be quite influential in shaping the structural organization of the local PhD programs in ELT. The other side of the coin is the core and source of the national reform in Turkey: European Commission surely aims to strengthen employability, mobility, and international competitiveness of the European workforce (de Wit, 2003) within the European higher education arena. In addition, strengthening the 'European dimension' of the higher education process as a part of European identity (Field, 1998) is another objective of the Commission throughout the socioeconomic expansion of the European Union. In this respect, the most important task for both sides is to strengthen the internationalization of the graduate programs in Turkey with international projects conducted in cooperation with the EU responsible bodies. Such pursuits may result in not only a better functioning doctoral level programs in Turkey but also a genuine coherence between the Turkish and the EU higher education systems in terms of mobility and employment dimensions. Similarly, it is Turkey's urgent and foremost task to support the NQF-HETR with nation-wide legislations to increase the non-academic employment rates of the doctoral graduates, specifically in governmental bodies as researchers, decision-makers and trainers. This will enable to bridge the scientific stance of the academy with the national decision-making processes in foreign language education.

In addition to those international and nation-wide actions to be taken at governmental level, four specific issues are identified within this review to be addressed by the Council of Higher Education and universities. Firstly, no official program ranking of the doctoral programs is available: Council of Higher Education or a similar authority is to yield and publish data concerning the impact on the quality of the doctoral programs. In addition, annual data on subject and research foci of the programs may help raise awareness across the programs. An annotated bibliographic index on doctoral dissertations published annually may help overcome the blind spots among the programs. Secondly, the dispositions on running comprehensive exams across programs are found to vary significantly from one program to another. While university and program culture is a value, there seems to be a necessity to define how comprehensive examinations are fulfilled in the programs in detail. Thirdly, more information should be provided specifically for the international students via guidelines, booklets, and videos. Such publications may increase the number of international students and program choice of the national students. Fourth and last policy suggestion relates to the quality assurance to be provided by the Council of Higher Education or a similar body. A well-defined and monitored external quality assurance system may contribute to the programs in many ways.

\section{References}

Alptekin, C., \& Tatar, S. (2011). Research on foreign language teaching and learning in Turkey (2005-2009), Language Teaching, 44(3), 328-353. http://dx.doi.org/10.1017/S026144481100005X

Borrell-Damien, L. (2009). Collaborative doctoral education: University-industry partnerships for enhancing knowledge exchange. Doc-careers projects. Report for European University Association.

Christensen, K. (2005). General rapporteur's report. Paper presented at Bologna seminar on doctoral programmes for the European Knowledge Society, February 3-5, in Salzburg, Austria.

Commission of the European Communities. (2003). Communication from the council and the European Parliament: Researchers in the European researcher area: One profession, multiple careers. Brussels. (18.7.2003). Retrieved from http://ec.europa.eu/research/fp6/mariecurie-actions/pdf/careercommunication_en.pdf

Council of Graduate Schools. (2008). Graduate education and the public good. Report for council of graduate schools. Washington, DC: Council of Graduate Schools.

Council of Higher Education. (2015). Higher Education System in Turkey. Retrieved from http://www.yok.gov.tr/en/web/uluslararasi-iliskiler/anasayfa

de Wit, K. (2003). The consequences of European integration for higher education. Higher Education Policy, 16(2), 161-178. http://dx.doi.org/10.1057/palgrave.hep.8300014 
European Higher Education Area. (2015). Bologna Process-European Higher Education Area. Retrieved from http://www.ehea.info/

Field, J. (1998). European dimensions. Education, training and the European Union. London: Jessica Kingsley.

Ginerva House. (2010). Postgraduate education in the UK. Report for Higher Education Policy Institute. Oxford: Higher Education Policy Institute.

Halse, C., \& Mowbray, S. (2011). The impact of the doctorate. Studies in Higher Education, 36(5), 513-525. http://dx.doi.org/10.1080/03075079.2011.594590

Kehm, B. M. (2004). Studies on higher education: Developing doctoral degrees and qualifications in Europe: Good practice and issues of concern - A comparative analysis. In J. Sadlak (Ed.), Doctoral studies and qualifications in Europe and the United States: Status and prospects (pp. 279-298). Bucharest: UNESCO-CEPES.

Nerad, M., \& Heggelund, M. (2008). Past differences, current commonalities and future trends in doctoral education in selected countries. Toward a global PhD?: Forces and forms in doctoral education worldwide. Seattle, WA: University of Washington Press.

NQF-HETR. (2015). National qualifications framework for higher education in Turkey (NQF-HETR): 8. Level (Associate's) Qualifications. Retrieved from http://tyyc.yok.gov.tr/?pid=35

Research Councils UK. (2009). The UK grad programme. Retrieved from http://www.rcuk.ac.uk/rescareer/ukgrad/default.htm.

Stapleton, P. (2013). Using conference submission data to uncover broad trends in language teaching: A case study of one conference over 30 years. Language Teaching Research, 17(2), 144-163. http://dx.doi.org/10.1177/1362168812460808

Thomson, P., \& Walker, M. (2010). Doctoral education in context. The changing nature of the doctorate and doctoral students. In P. Thomson, \& M. Walker (Eds.) The Routledge doctoral student's companion (pp. 9-26). New York, NY: Routledge.

Wellington, J. (2013). Searching for 'doctorateness'. Studies in Higher Education, 38(10), 1490-1503. http://dx.doi.org/10.1080/03075079.2011.634901

\section{Notes}

Note 1. ECTS: The European Credit Transfer and Accumulation System is a tool that helps to design, describe, and deliver study programs and awards higher education qualifications in the European higher education arena. One ECTS credit defines 25-30 hours of course work.

Note 2. ISCED: International Standard Classification of Education, developed by UNESCO, is offered as a tool for collection of education statistics and comparable indicators, for compiling and their presentation at both national and international level. 